\title{
Correction to: Design and implementation of a maxi-sized mobile robot (Karo) for rescue missions
}

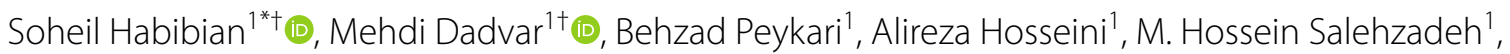
Alireza H. M. Hosseini ${ }^{1}$ and Farshid Najafi ${ }^{2}$

\section{Correction to: Robomech J (2021) 8:1}

https://doi.org/10.1186/s40648-020-00188-9

Following publication of the original article [1], the authors reported an error occured during the production process in affiliation and dagger symbol that is listed in the footnote of page 5 of the document (A2) should be added as a superscript.

The original article [1] has been updated.

\section{Reference}

1. Habibian S, Dadvar M, Peykari B, Hosseini A, Salehzadeh MH, Hosseini AHM, Najafi F (2021) Design and implementation of a maxi-sized mobile robot (Karo) for rescue missions. Robomech J 8:1. https://doi.org/10.1186/ s40648-020-00188-9

\section{Publisher's Note}

Springer Nature remains neutral with regard to jurisdictional claims in published maps and institutional affiliations.

\section{Author details}

${ }^{1}$ The Authors Were With Advanced Mobile Robotics Lab, Qazvin Azad

University, Qazvin, Iran. ${ }^{2}$ University of Tehran, College of Engineering, School

of Mechanical Engineering, Tehran, Iran.

Published online: 22 February 2021

The original article can be found online at https://doi.org/10.1186/s4064 8-020-00188-9.

\footnotetext{
*Correspondence: habibian@vt.edu

tSoheil Habibian and Mehdi Dadvar contributed equally in this paper

${ }^{1}$ The Authors Were With Advanced Mobile Robotics Lab, Qazvin Azad

University, Qazvin, Iran

Full list of author information is available at the end of the article
}

\section{Springer Open}

(c) The Author(s) 2021. This article is licensed under a Creative Commons Attribution 4.0 International License, which permits use, sharing adaptation, distribution and reproduction in any medium or format, as long as you give appropriate credit to the original author(s) and the source, provide a link to the Creative Commons licence, and indicate if changes were made. The images or other third party material in this article are included in the article's Creative Commons licence, unless indicated otherwise in a credit line to the material. If material. is not included in the article's Creative Commons licence and your intended use is not permitted by statutory regulation or exceeds the permitted use, you will need to obtain permission directly from the copyright holder. To view a copy of this licence, visit http://creativecommons.org/licenses/by/4.0/ 